\title{
Notes on Boronia (Rutaceae) in New South Wales, including descriptions of three new species
}

\author{
Peter H. Weston
}

\begin{abstract}
Weston, Peter H. (National Herbarium of New South Wales, Royal Botanic Gardens, Sydney, Australia 2000) 1990. Notes on Boronia (Rutaceae) in New South Wales, including descriptions of three new species. Telopea 4(1): 121-128. Three new species are described: $B$. chartacea, $B$. umbellata, and $B$. warrumbunglensis. I also discuss the taxonomic status of $B$. whitei and four taxa that had previously been given informal names.
\end{abstract}

In Jacobs and Pickard (1981) seven unnamed species of Boronia were listed for New South Wales as spp. A-G. In the course of preparing a treatment of Boronia for the forthcoming second volume of the Flora of New South Wales (Weston \& Porteners in prep.), I concluded that at least three of these taxa, C, E and G, warranted formal recognition as species. In this paper these species are described and the systematics of the other unnamed taxa is discussed.

\section{New species}

All three of the new species described below belong to the informal ' $B$. ledifolia group' of Weston, Carolin \& Armstrong (1984). Below is a description that summarises the characters shared by all of the taxa in this group. Some preliminary comments on morphological terminology are necessary.

All taxa in the B. ledifolia group, as well as B. lanceolata and all taxa in the B. bowmanii, $B$. grandisepala, and B. affinis groups (see Weston et al. (1984: Appendix 1) for ostensive definitions of these groups) have the same, distinctive inflorescence structure (Figure 1). The inflorescences are exclusively axillary, subtended by foliage leaves. In the terminology of Briggs \& Johnson (1979) the inflorescences are 2-nodate botryoids in which the second (i.e. non-basal) internode of the primary axis and the basal internodes of the secondary axes (if developed) are reduced to vestiges. All pherophylls are closely clustered together and when three or more flowers are developed, the inflorescence appears umbellate. In most species the prophylls of the primary axis have a minute lamina, and in some species, such as B. warrumbunglensis, these prophylls may be minutely compound.

Where hairs are present, their density is classified as sparse (only a few, scattered hairs), moderately dense (more than a few scattered hairs but not so dense that the underlying epidermis is obscured), or dense (obscuring the underlying epidermis).

Most species in the $B$. ledifolia group have adult leaves that are either glabrous or almost so (subgroup 1) or densely stellate-tomentose abaxially (subgroup 2). B. mollis is the only species of the $B$. ledifolia group native to eastern Australia that does not fall into either of these classes, having moderately stellate-tomentose abaxial leaflet surfaces. However, the seedling leaves and basal leaves in regenerating shoots are glabrous or almost so in all taxa for which I have seen appropriate material. In species of subgroup 2 , there is an abrupt transition from the production of glabrous (or almost glabrous) 
leaves to abaxially densely stellate-tomentose leaves. Nelson's direct method of character analysis (see Weston 1988) can be applied in this case: adult leaves with a glabrous or almost glabrous abaxial surface are more general than, and thus plesiomorphous relative to, adult leaves that are densely stellate-tomentose abaxially. Care must be taken to examine adult leaves when using this feature in identifying specimens.

The number in brackets that follows each heading of 'selected specimens' is the total number of specimens examined.

Boronia ledifolia group (Weston et al. 1984: 202-203)

Hairs mostly stellate. Inflorescence a 2-nodate botryoid (Figure 1), axillary; pherophylls persistent. Sepals valvate, persistent in mature fruit, shorter than the petals. Petals valvate, with the midvein prominently raised abaxially, persistent in mature fruit; tip straight, apical (neither incurved nor subterminal on the abaxial surface). Staminal filaments clavate, bearing the anthers apically, bearing stiff hairs on the abaxial surface and margins below the swollen tip, prominently glandular on the swollen tip, each gland usually bearing a minute stellate hair; antisepalous filaments longer than antipetalous. Anthers basifixed, monomorphic. Style attaching terminally on the ovary. Stigma rounded, not or scarcely wider than the style. Seeds black, dull due to the minutely colliculate surface of the testa.

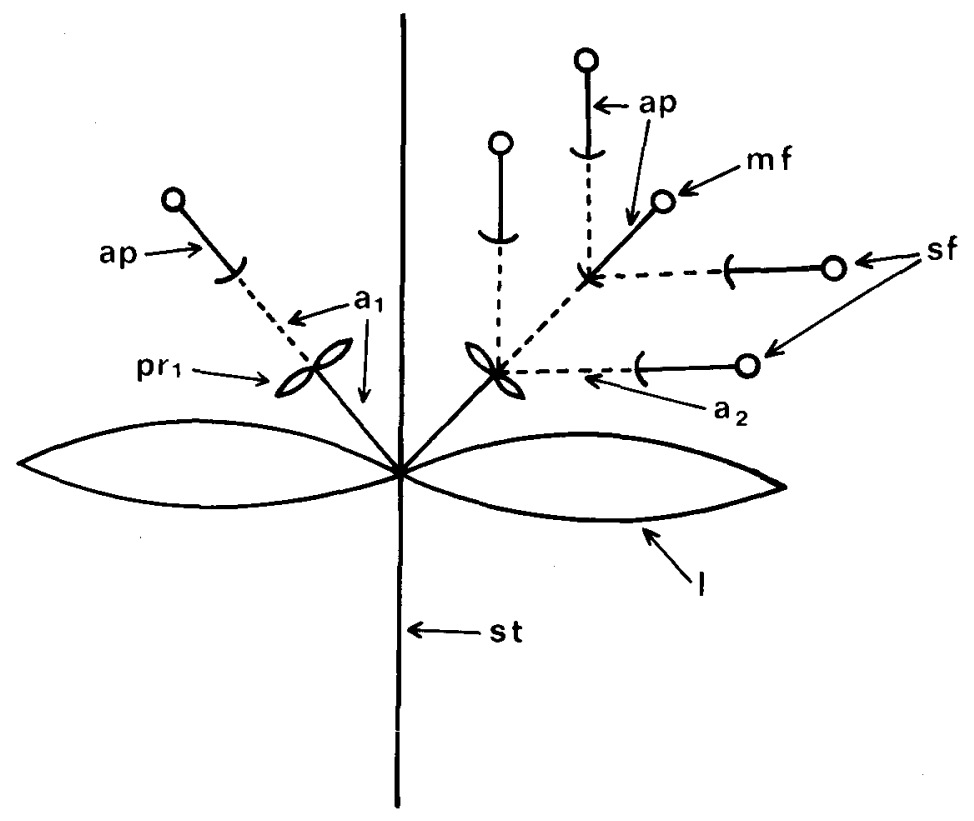

Figure 1. Diagramatic representation of inflorescence types in the $B$. ledifolia group. The inflorescence in the right-hand axil is typical of $B$. umbellata, while that in the left-hand axil is typical of $B$. chartacea and $B$. warrumbunglensis. Axes that do not elongate are represented by dotted lines. $a_{1}, a_{2}=$ primary and secondary axes respectively, ap = anthopodium, $1=$ leaf, $\mathrm{mf}=$ median flower, $\mathrm{pr}_{1}=$ prophylls of primary axis, $\mathrm{sf}=$ side flower, $\mathrm{st}=$ stem of leafy shoot. 


\section{Boronia chartacea $P$. Weston, sp. nov.}

Ramuli stellato-tomentosi. Folia unifoliolata, chartacea; petiolus 1-2 mm longus; pagina adaxialis laminae prominenter glanduloso-verrucosa; pagina abaxialis laminae dense stellato-tomentosa; margines glanduloso-denticulati. Inflorescentiae axillares, 1(-3)-floribus. Petala valvata, rosea, costa abaxiali prominenter elevata, in statu maturo fructifero persistentia.

Holotype: New SOUTH WALES: North Coast: Newry State Forest, $1.9 \mathrm{~km} \mathrm{~S}$ of Urunga, $30^{\circ} 32^{\prime} S 152^{\circ} 58^{\prime} \mathrm{E}$, R.G. Coveny 4603, 13.9 .1972 (NSW). IsOTYPES (n.v.): AD, BRI, CANB, CBG, K, MEL, PERTH.

[B. sp. C (aff. rosmarinifolia) in Jacobs \& Pickard (1981: 191)]

Shrub, 0.4-2.7 $\mathrm{m}$ high. Branchlets moderately stellate-tomentose, terete to slightly angular, not obviously glandular. Leaves unifoliolate, chartaceous; petiole 1-2 mm long; lamina linear-elliptic to narrow-elliptic or narrow-oblong, acute to obtuse, 20-48 $\mathrm{mm}$ long, 2-5 mm wide, flat; adaxial surface prominently glandular-verrucose, glabrous or with a few scattered stellate hairs on the faintly impressed midvein; abaxial surface densely stellate-tomentose (and thus much paler than adaxial surface) except for the moderately stellate-tomentose, prominently protruding midvein; margins glandular-denticulate, recurved to revolute. Inflorescences 1(-3)-flowered; peduncle $0.5-1.5 \mathrm{~mm}$ long, densely stellate-tomentose; prophylls of primary axis minutely unifoliolose, 1.0-3.0 mm long, moderately stellate-tomentose. Anthopodia 4-8 mm long, moderately stellate-tomentose. Sepals ovate to broad-ovate, $2.0-3.5 \mathrm{~mm}$ long, 1.4-2.5 mm wide, densely and minutely pubescent near the margins but becoming glabrous towards the base adaxially, densely stellate-tomentose abaxially. Petals bright pink, 7-9 mm long, sparsely simple pubescent adaxially, moderately tomentose abaxially. Basal hairs of staminal filaments mostly simple. Anther appendage minute. Gynoecium glabrous. Cocci glabrous.

DERIVATION OF EPITHET: Latin chartaceus, papery, referring to the thin leaves, which are very brittle when dried.

\section{FloWERING PERIOD: August to October.}

DISTRIBUTION AND HABITAT: In gullies and along creek lines, in wet sclerophyll forest, on sandstone or granitic substrates, at altitudes from 70 to $300 \mathrm{~m}$, disjunctly distributed in the Wauchope, Urunga and Grafton areas of north-eastern New South Wales. Figure 2.

Notes: $B$. chartacea most closely resembles B. rosmarinifolia and B. ledifolia. Both of these species are distinguished from $B$. chartacea by their tougher, not chartaceous leaves, which are not prominently glandular-verrucose and which have entire margins. $B$. ledifolia also differs in having unifoliolate to pinnate leaves, and $B$. rosmarinifolia differs in having sessile leaves. $B$. chartacea is sympatric with, but ecologically separated from, $B$. rosmarinifolia in the Grafton area, occurring in wet sclerophyll forest in gullies while $B$. rosmarinifolia occurs in dry sclerophyll forest on ridge-tops in this area.

Selected Specimens (14): New South Wales: North Coast: Cabbage Tree Creek, Whiporie, Benson 124 \& Dodson, 4.6.1984 (NSW); Whiteman Ck and Coaldale Rd, c. 20 miles NNW of Grafton, Grieves s.n., 11.8.1969 (NSW); 'The Punchbowl", near Copmanhurst, O'Grady s.n., 8.1970 (NSW); Bril Bril Ck, Bellangry StateForest, Constable NSW 66836, 15.10.1961 (NSW); Wilson R. above Wild Bull picnic area, $31^{\circ} 15^{\prime} \mathrm{S} 152^{\circ} 31^{\prime} \mathrm{E}$, Whaite 3680, 24.8.1980 (NSW).

\section{Boronia umbellata $P$. Weston, sp. nov.}

Ramuli dense stellato-tomentosi. Folia 1-5-foliolata, chartacea; pagina adaxiali foliolorum fere glabra; pagina abaxiali foliolorum dense stellato-tomentosa; foliolum terminale plerumque anguste ellipticum, 25-58 $\mathrm{mm}$ longum, 6-16 mm latum. 
Inflorescentiae axillares, 2-6-floribus. Anthopodia 6-16 $\mathrm{mm}$ longa. Sepala ovata, 3.0-3.5 mm longa, 1.6-2.0 mm lata. Petala valvata, rosea, costa abaxiali prominenter elevata, in statu maturo fructifero persistentia.

Holotype: New South Wales: North Coast: Sherwood Creek, $28 \mathrm{~km} \mathrm{NW}$ of Coffs Harbour, $30^{\circ} 03^{\prime} \mathrm{S} 153^{\circ} 03^{\prime} \mathrm{E}, \mathrm{H}$. Streimann 8124, 11.10.1978 (CBG).

ISOTYPES: K, MEL, NSW, PERTH.

[B. sp. E (aff. mollis) in Jacobs \& Pickard (1981: 191)]

Shrub, c. $1 \mathrm{~m}$ high. Branchlets densely stellate-tomentose, terete, not obviously glandular. Leaves mostly pinnate with 3-5 leaflets but unifoliolate at the 1-3 most basal nodes of an axillary shoot, chartaceous, glandular but not prominently so; petiole $8-17$ $\mathrm{mm}$ long; rachis to $20 \mathrm{~mm}$ long, winged; leaflets entire, with recurved margins, with an obtuse to rounded tip, glabrous adaxially except for stellate hairs scattered along the impressed midvein, densely stellate-tomentose (and thus much paler) abaxially except for the moderately stellate-tomentose, prominently protruding midvein; terminal leaflet usually narrow-elliptical, 1.4-2.5 times as long as the lateral leaflets, 25-58 mm long,

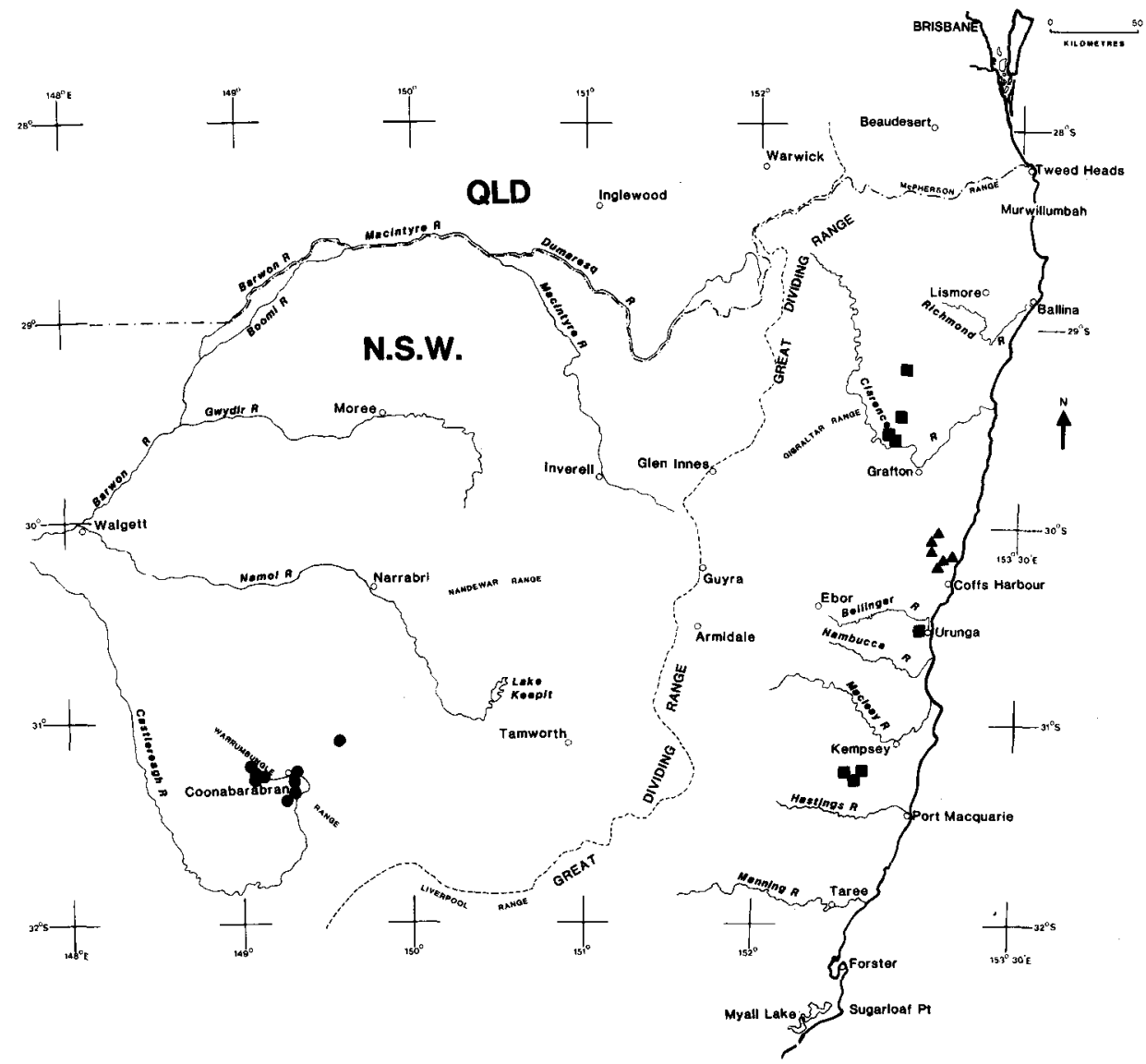

Figure 2. Distributions of B. chartacea (square), B. umbellata (triangle), and B. warrumbunglensis (circle). 
6-16 mm wide, usually less obtuse than lateral leaflets; lateral leaflets narrowly to broadly elliptical or sometimes spathulate or oblong, 15-35 mm long, 6-12 mm wide. Inflorescences sometimes paired in the axil, 2-6(-9)-flowered, sometimes with an accessory flower in the axils of some pherophylls; peduncle $0.5-11 \mathrm{~mm}$ long, densely stellate-tomentose; prophylls of primary axis minutely unifoliolose to cataphyllous, 1.0-4.0 mm long, densely stellate-tomentose or with indumentum similar to that of a foliage leaf. Anthopodia 6-16 mm long, moderately stellate-tomentose. Sepals ovate, $3.0-3.5 \mathrm{~mm}$ long, $1.6-2.0 \mathrm{~mm}$ wide, densely and minutely pubescent near the margins but becoming glabrous towards the base adaxially, moderately stellate-tomentose abaxially. Petals pink, 7-10 mm long, moderately simple-pubescent adaxially, moderately to densely stellate-tomentose abaxially. Basal hairs of staminal filaments mostly stellate. Anther appendage minute. Gynoecium glabrous. Cocci glabrous.

DERIVATION OF EPITHET: Latin umbellatus, like an umbrella, referring to the umbel-like inflorescences.

Flowering Period: August to October.

DISTRIBUTION AND HABITAT: In sclerophyll forest on sandstone and metasediments, at altitudes from 100 to $600 \mathrm{~m}$, restricted to the coastal ranges between Athol Glen and Coramba, north of Coffs Harbour, north-eastern New South Wales. Figure 2.

Notes: Cheel (1927) included specimens of B. umbellata within his concept of $B$. rubiginosa Cunn. ex Endl. This species, however, differs from $B$. umbellata in leaflet morphology (terminal leaflet 7-18 $\mathrm{mm}$ long, 3-6 $\mathrm{mm}$ wide, not more acute than lateral leaflets; lateral leaflets 4-14 $\mathrm{mm}$ long, 2-6 $\mathrm{mm}$ wide), and in having leaves with (1-)3-9 leaflets, lacking the transition from basal, unifoliolate leaves to trifoliolate or pinnate leaves in axillary shoots. $B$. umbellata superficially resembles $B$. mollis, which differs in having leaflets that are moderately stellate-tomentose abaxially, and sparsely stellate-tomentose adaxially, and in its narrow-triangular sepals. The shorter stellate hairs of $B$. umbellata give it a 'tidier', less shaggy tomentum than $B$. mollis. On average $B$. umbellata also has larger leaves with fewer leaflets than $B$. mollis. B. umbellata has also been confused with $B$. keysii, a species that is restricted to the Gympie area in south-east Queensland and that has virtually glabrous, 1-7-foliolate leaves with narrower leaflets than $B$. umbellata.

One specimen, Burgess 282, is labelled 'Pittwater, Sydney, 3/9/1973'. Almost certainly this specimen has been wrongly labelled. Burgess collected $B$. umbellata at Waihou trig on 25/8/1973 and it seems likely that Burgess 282 was collected in the Coffs Harbour area and accidentally given the label of a specimen collected a few days later.

Selected SPecimens (9): New South Wales: North Coast: Waihou trig, Burgess 268, 25.8.1973 (CBG, NSW); Wedding Bells State Forest, Gray s.n., 8.9.1953 (NSW); Nana Glen, Shiress s.n., 9.1924 (NSW); $15 \mathrm{~km}$ from Moonee Creek turn off to Lower Bucca, Steley s.n., 12.1974 (BRI, NSW); Mt Coramba, Boorman s.n., 11.1912 (NSW).

Boronia warrumbunglensis $P$. Weston, sp. nov.

Ramuli stellato-tomentosi. Folia pinnata, 3-7-foliolata, firma, glabra vel fere glabra; petiolus $1.5-7 \mathrm{~mm}$ longus; foliola 4-16 mm longa, $1.0-3.0 \mathrm{~mm}$ lata, anguste oblonga, obtusa. Inflorescentiae axillares, 1-2-floribus; pedunculus 0.5-1.0 mm longus. Petala valvata, rosea, costa abaxiali prominenter elevata; in statu maturo fructifero persistentia.

Holotype: New SOUTH WALES: North Western Slopes: Oxley Hwy, c. $10 \mathrm{~km} S$ of Coonabarabran, $31^{\circ} 23^{\prime} \mathrm{S} 149^{\circ} 15^{\prime} \mathrm{E}$, M.G. Corrick 5883, 9.9.1977 (NSW).

ISOTYPE (n.v.): MEL. 
[B. sp. G (aff. granitica) in Jacobs \& Pickard (1981: 191)]

Shrub, 0.3-1 m high. Branchlets moderately stellate-tomentose, terete, not obviously glandular. Leaves pinnate with 3-7 leaflets, firm, glandular-punctate; petiole 1.5-7 mm long, rachis $2-12 \mathrm{~mm}$ long, winged; leaflets entire, glabrous or rarely very sparsely stellate-hairy, 4-16 mm long, 1.0-3.0 mm wide, narrow-oblong, obtuse, slightly paler below; margins recurved; terminal leaflet 1-2 times longer than lateral leaflets. Inflorescences 1-2-flowered; peduncle $0.5-1.0 \mathrm{~mm}$ long, densely stellate-tomentose; prophylls of primary axis cataphyllous to minutely unifoliolose to trifoliolose, 1.0-2.5 $\mathrm{mm}$ long, densely stellate-tomentose. Anthopodia 3-7 mm long, densely stellatetomentose. Sepals ovate, $3.0-3.5 \mathrm{~mm}$ long, $1.6-2.0 \mathrm{~mm}$ wide, densely and minutely pubescent near the margins but becoming glabrous towards the base adaxially, densely tomentose abaxially. Petals pink, 5-7 mm long, moderately pubescent adaxially, moderately to densely tomentose abaxially. Basal hairs of staminal filaments simple or stellate. Anther appendage minute. Gynoecium glabrous. Cocci sparsely to moderately covered with stiff, simple to stellate hairs.

DERIVATION OF EPITHET: Refers to its restricted occurrence in the Warrumbungle Mountains and nearby areas.

Flowering PERIOD: August to October.

DISTRIBUTION AND HABITAT: In dry sclerophyll forest on sandstone, at altitudes between 500 and $600 \mathrm{~m}$, restricted to the Warrumbungle Mountains - Coonabarabran district. Figure 2.

NOTES: B. warrumbunglensis most closely resembles B. ruppii, B. glabra and B. granitica. $B$. glabra differs from $B$. warrumbunglensis in its consistently unifoliolate, sessile leaves. B. ruppii differs in its narrowly to broadly elliptical to spathulate leaflets and in its longer peduncles (2-15 mm long). B. granitica differs in its young leaves and branchlets being moderately hirsute with long white hairs.

B. warrumbunglensis and B. glabra are broadly sympatric but no specimens intermediate between them have been collected.

Selected SPecimens (21): New South Wales: North Western Slopes: Rocky Glen, Boorman s.n., 9.1908 (NSW); Coonabarabran - Narrabri road, McMair N/04, N/07, 20.8.1976 (NSW); ridge near Mt Wheoh, Harden 15, 8.1975 (NSW); Timor Rock, Harden 16-17, 8.1975 (NSW); Siding Spring, Overall NSW 122243, 17.9.1967 (NSW); Warrumbungle Ra, $19 \mathrm{~km}$ WSW of Coonabarabran, $2.0 \mathrm{~km}$ E of Burrumbuckle Rock, $31^{\circ} 20^{\prime} \mathrm{S} 149^{\circ} 05^{\prime} \mathrm{E}$, Crisp 4355, 10.10.1978 (CBG, NSW).

\section{Notes on some formal and informal taxa listed for New South Wales in Jacobs \& Pickard (1981)}

\section{B. whitei Cheel}

In describing $B$. whitei, Cheel compared it with $B$. alulata and B. granitica, but did not discuss the morphological distinction between it and $B$. ledifolia, other than remarking that 'It is quite distinct from $B$. denticulata, B. rubiginosa and B. triphylla $[=B$. ledifolia]' (Cheel 1927: 406). However, he described the leaves of $B$. whitei as 'pinnate, 5-9 leaflets' (Cheel 1927: 405) and presumably regarded B. ledifolia and B. triphylla as consistently unifoliolate and trifoliolate, respectively. The geographic distribution was reported as Tent Hill, New England, Emmaville, Torrington, and Bismuth.

Since 1927 a number of specimens have been collected that have blurred the distinction between $B$. ledifolia and $B$. whitei. Firstly, some specimens from the Torrington area are trifoliolate, but in all other respects they resemble other specimens of $B$. whitei. 
Secondly, a number of pinnate-leaved specimens, that seem morphologically indistinguishable from typical $B$. whitei, have been collected from the Putty Road and nearby areas on sandstone between the Hunter Valley and Colo. The populations from which these specimens were sampled apparently intergrade with typical $B$. ledifolia in the area between Kulnura and Maroota. This situation is complicated by the fact that plants of $B$. ledifolia often show an ontogenetic transition from pinnate juvenile leaves to trifoliolate or unifoliolate adult leaves. Since it is impossible to distinguish $B$. whitei from $B$. ledifolia using available morphological evidence, Weston and Porteners (in prep.) have treated the former name as a synonym of the latter.

\section{'Boronia sp. $\mathrm{A}^{\prime}$}

This informal name was used to designate specimens from the Fitzroy Falls - Belmore Falls and Nerriga areas, which seemed to differ from $B$. deanei in their longer, more acute, flatter leaves and larger flowers. Prior to Jacobs \& Pickard (1981), very few collections of $B$. deanei had been made and it was thought to be restricted to the Clarence-Wolgan area and Kanangra-Boyd plateau. In 1981, D.H. Benson and H. Bryant re-collected $B$. deanei extensively in the Clarence area, and these specimens, together with a more recent collection from Nalbaugh National Park, near Eden, seem to 'blur' the distinction between $B$. deanei and B. sp. A. In particular, there is an ontogenetic transition in $B$. deanei from longer, flatter, acute leaves to shorter almost terete, obtuse leaves. Also, there is some overlap in flower dimensions between the two samples. Consequently, Weston and Porteners (in prep.) have treated them as synonymous. Nevertheless, specimens referred to $B$. sp. A differ in overall appearance from $B$. deanei and they may well be morphometrically separable.

'Boronia sp. B (aff. rosmarinifolia)'

When 'Plants of New South Wales' (Jacobs \& Pickard 1981) was published, this taxon was represented by a single fruiting collection at NSW (Burbong near Gilgandra, McReaddie NSW 122247, 3.12.1960). This specimen differs from B. glabra, the other species of the $B$. ledifolia group present in this area, in having leaves that are densely tomentose abaxially. McReaddie NSW 122247 has moderately hairy cocci and thus differs from B. rosmarinifolia, a coastal species with glabrous cocci. Since 1981, a flowering specimen, possibly belonging to the same taxon as McReaddie's specimen, has been collected (Pilliga Scrub, Forest Way, c. $25 \mathrm{~km} \mathrm{~W}$ from Newell Hwy, 30 $38^{\circ} \mathrm{S}$ $149^{\circ} 24^{\prime} \mathrm{E}$, Walsh 1336, 14.8.1984 (CANB, MEL, NSW)). Since these specimens are very similar to, but do not match, B. glabra and B. rosmarinifolia, it seems reasonable to assign them tentatively to an unnamed species. However, it is premature to recognise this taxon formally without sampling it more adequately.

\section{'Boronia sp. D (aff. rubiginosa)'}

This informal name was used for a large-flowered population from the Nandewar Ranges which, for characters other than flower size, matches $B$. rubiginosa. The latter is a patchily distributed species that shows geographic variation in other characters such as leaflet number, and it seems reasonable to regard the Nandewar population as an allopatric variant, rather than as a separate taxon. The taxonomic status of $B$. rubiginosa is unclear in some respects. It seems to be parapatric with $B$. ledifolia and these taxa may intergrade in the upper Hunter River valley. However, Cheel's (1927) inclusion of specimens from Cowan Creek, Berowra and Hawkesbury River within B. rubiginosa was mistaken: these are juvenile, pinnate-leaved specimens of $B$. ledifolia.

'Boronia sp. F (aff. ruppii)'

B. ruppii is patchily distributed, with populations in the Barraba, Merriwa and Berrima areas, and near the Colo and lower Nepean Rivers from Glen Davis to Kenthurst. The 
geographically isolated populations differ from one another, particularly in the density of stellate hairs on the abaxial surfaces of the sepals and petals. For example, in the specimens from near Glen Davis and Berrima the abaxial surface of the sepals is glabrous and that of the petals sparsely stellate-tomentose, while in specimens from the Barraba area they are densely stellate-tomentose. These extreme variants are linked by morphologically intermediate populations from other localities. $B$. sp. F represents a morphologically undefined, apparently random sample of specimens of $B$. ruppii.

\section{Acknowledgements}

I am grateful to Peter Wilson and Jim Armstrong for critically reading the manuscript, to Marianne Porteners for assisting in scoring data and to David Mackay for drawing Figure 1 and to Peter Richards and Dianne Godden for drawing Figure 2.

\section{References}

Briggs, B.G. \& Johnson, L.A.S. (1979) Evolution in the Myrtaceae - evidence from inflorescence structure. Proc. Linn. Soc. New South Wales 102: 157-256.

Cheel, E. (1927) Descriptions of four new species of Boronia with notes on certain other species. J. \& Proc. Roy. Soc. New South Wales 61: 401-414.

Jacobs, S.W.L. \& Pickard, J. (1981) Plants of New South Wales (Govt Printer: Sydney).

Weston, P.H. (1988) Indirect and direct methods in systematics. Pp. 27-56 in Humphries, C.J. (ed.), Ontogeny and Systematics (Columbia Univ. Press: New York).

Weston, P.H., Carolin, R.C. \& Armstrong, J.A. (1984) A cladistic analysis of Boronia Sm. and Boronella Baill. (Rutaceae). Aust. J. Bot. 32: 187-203.

Weston, P.H. \& Porteners, M. (in prep.) Boronia. In Harden, G. (ed.) Flora of New South Wales. 